\title{
INTERSEÇÃO ENTRE LITERATURA E FILOSOFIA: \\ O PENSAMENTO MAQUINÍSTICO DE MARTIN HEIDEGGER \\ EM O ALIENISTA DE MACHADO DE ASSIS
}

\section{INTERSECTION BETWEEN LITERATURE AND PHILOSOPHY: \\ MARTIN HEIDEGGER'S THE TECHNICAL THINKING AS A BACKGROUND TO READ THE SHORT STORY O ALIENISTA BY MACHADO DE ASSIS}

\section{Ângela Maria Rubel Fanini ${ }^{\star}$}

RESUMO: Neste artigo analisa-se o conto O Alienista, de Machado de Assis, sob a luz da reflexão que Martin Heidegger desenvolve na obra Serenidade (1955). Procura-se demonstrar que o autor brasileiro, ao destacar o pensamento e a atitude calculística de forma satírica na personagem principal, Simão Bacamarte, propicia ao leitor a possibilidade de reflexão e desalienação em relação ao universo tecnicista que o tem enredado, conforme é problematizado pelo filósofo alemão. PALAVRAS-CHAVE: Pensamento tecnicista, objetificação, Literatura Brasileira, pensamento de reflexão.

ABSTRACT: This paper examines the short story O Alienista written by Brazilian writer Machado de Assis through Martin Heidegger's theoretical view, specifically located in Serenidade (1955), an essay, in which German philosopher contrasts two different ways of thinking, that is, the technical one linked to assertion, logic, science and technology and another one that is not an instrument of calculation and domination. It is focused Simão Bacamarte, the main character, who is dominated by the technical thinking, in order to prove that Literature discloses some possibilities of confronting that dominant position.

KEYWORD: Technical thinking, reification, Brazilian Literature, genuine thinking.

\footnotetext{
* Universidade Tecnológica Federal do Paraná (UTFPR), Curitiba/PR.
} Professora Doutora em Teoria da Literatura.Email: rubel@utfpr.edu.br. 



\section{INTERSEÇÃO ENTRE LITERATURA E FILOSOFIA: O PENSAMENTO MAQUINÍSTICO DE MARTIN HEIDEGGER EM O ALIENISTA DE MACHADO DE ASSIS}

\section{Machado e Heidegger: por uma crítica a favor do discurso de reflexão}

Este artigo se propõe a analisar o conto O Alienista, ${ }^{1}$ de Machado de Assis, a partir das considerações que Martin Heidegger elabora na conferência Serenidade, ${ }^{2}$ destacando-se a trajetória da personagem principal, cuja atitude e ideias vinculam-se ao pensamento técnico de que trata o filósofo alemão. Espera-se aqui problematizar as interseções e as articulações entre Filosofia e Literatura, com o objetivo de fazer uma leitura que leve a uma reflexão engajada no sentido de contribuir para repensar o modo como nos relacionamos com o nosso entorno. Partindo da premissa de Heidegger, para quem há que se resgatar a essência do homem, ou seja, sua capacidade de pensar e de refletir, tomamos o discurso literário como forma de concretizar essa essência, haja vista que, a partir dele, é possível se aproximar das coisas, do outro e dos fatos de modo reflexivo. Este estudo liga-se à linha de pesquisa de estudos de pós-graduação em que

\footnotetext{
${ }^{1}$ ASSIS, Machado. O Alienista. Porto: Alegre: L\&PM, 2008. Doravante as citações dessa obra se referem a essa edição.

${ }^{2}$ Discurso pronunciado em 30 de outubro de 1955, quando da celebração do $175^{\circ}$ aniversário do nascimento do compositor Conradin Kreutzer, em Messkirch.
} 
se procura refletir sobre as articulações entre o universo da tecnologia e o da cultura.

Os estudos filosóficos sobre as articulações entre a tecnologia e a sociedade são de data recente, aparecendo mais sistematicamente no século XX. Objetivando-se entender como ocorrem essas interseções, é necessário pensar sobre como elas são representadas e problematizadas pelos intelectuais. Nesse sentido, encontram-se inúmeras obras que tratam da tecnologia por diferentes vieses, ou seja, vendo-a como instrumental, neutra, autônoma ou carregada de valores. Ampla e complexa discussão sobre o caráter determinista e essencialista da tecnologia se encontra nas obras de Marshal Macluhan (1969), Herbert Marcuse (1979) e Martin Heidegger, para quem, salvaguardadas as devidas diferenças, a tecnologia não se constitui tão somente de artefatos técnicos, mas constrói um modo de vida, moldando a sociedade a partir de uma tecnocracia, tendo poder de influenciar a cultura, o comportamento, os valores, a comunicação e a linguagem do ser humano.

A discussão mais explícita sobre esse determinismo tecnológico em Heidegger se encontra nos textos "Serenidade" e "A questão da técnica". Para este artigo, será focalizado apenas o primeiro, que se compõe de duas partes, sendo que a primeira é resultado de uma conferência para um público leigo. Aí, resumidamente, Heidegger destaca os perigos da ausência de pensamento reflexivo por parte dos homens e de como isso provoca um verdadeiro "desenraizamento" do ser em relação à sua essência, ou seja, à sua capacidade de pensar e de meditar. A segunda parte consiste em um diálogo fictício entre o filósofo e dois colegas em que prossegue a discussão sobre os perigos que cercam os homens quando do domínio e da hegemonia do pensar técnico.

A discussão heideggeriana sobre essas interações destaca a longa história da formação do homem ocidental, enredado cada vez mais em um pensamento calculístico em busca do controle sobre todos e tudo. Essa vontade de poder sobre as coisas se exacerba nos dois últimos séculos em uma sociedade em que se intensifica a criação de aparelhos, artefatos e equipamentos tecnológicos que procuram controlar o homem e seu entorno. Essa "relação fundamentalmente técnica do homem com o todo do mundo" se vincula sobretudo à Revolução Industrial na Inglaterra, no século XVII, às ideias liberais-burguesas e ao modo de produção capitalista em que ciência e tecnologia se associam de modo bastante pragmático. Esse paradigma tecnicista se espraia para fora das fronteiras europeias, reproduzindo-se e ampliando-se pelas Américas, atingindo também o universo das ideias no Brasil. 
Para Heidegger, o aprisionamento do homem ocidental nesse horizonte tem se exacerbado e isso tem gerado o afastamento do homem de um outro tipo de pensamento, denominado reflexivo, em que não se procura a objetificação das coisas. Para esse outro olhar, a relação entre as palavras e as coisas é menos redutora, permitindo que estas possam emergir, sem, contudo, serem definidas e denominadas por completo, finalizando-as e reduzindo-as. No império do pensamento calculista, a linguagem já não é a "morada do ser", mas se acha tomada por razão tecnicista que representa os seres encapsulados em certas definições que os limitam. Longe se está de um pensamento reflexivo que ousa entender coisas, pessoas e fatos fora do paradigma maquinístico. Heidegger trabalha com a noção de aletheia, destacando que ao referente deve ser dada a possibilidade de emergir, "apresentado-se" de modo diferente da representação objetificante. Essa possibilidade de outra visão e apresentação só se viabiliza a partir de outra matriz discursiva em que impera o pensamento reflexivo e não técnico. Heidegger vai depositar esperança na linguagem poética como alternativa para se escapar do pensamento calculista por entender que ela possibilita a atitude reflexiva, longe da vontade de poder e do controle sobre o mundo. Heidegger busca outras palavras e termos da tradição filosófica grega para resgatar a forma reflexiva de repensar as coisas. Traz de Heráclito a palavra "aproximar-se", que indica o cuidado com a coisa, afastando-se de uma atitude de domínio sobre ela. Aí reside uma posição ética com a coisa, em que não se intenta exauri-la e torná-la objeto. Tal qual os poetas o fazem, buscando outros vocábulos que não os já desgastados e petrificados pelo uso banalizador, tentando, com isso, demonstrar outras facetas inusitadas sobre os fatos poéticos. A palavra advogada por Heidegger, e que se encontra no âmago do poético, não é a palavra descritiva, e, sim, a que se aproxima com cautela e com "serenidade" das coisas, revelando muito mais a ambiguidade, a vagueza, o fluido e a impossibilidade de representar a coisa tal qual ela é. Posiciona-se contrário à representação e à descrição.

O filósofo alemão enfatiza o embotamento do homem, resultante de um pensamento maquinístico que oblitera as capacidades reflexiva e de meditação. Na ânsia de tudo abarcar para controlar, falta-lhe a "serenidade" diante dos fatos e o esperar pelo "desocultamento do ser". Nessa mecânica de posse cada vez mais acentuada sobre as coisas, o homem impede que outro tipo de pensamento se aloje em si e isso, segundo o autor, leva a uma pauperização mental, como o destacado: 
Não nos iludamos. Todos nós, mesmo aqueles que pensam por dever profissional, somos muitas vezes pobres-em-pensamentos: ficamos sem-pensamentos com demasiada facilidade. A ausência-de-pensamento é um hóspede sinistro que, no mundo actual, entra e sai em toda a parte. Pois, hoje, toma-se o conhecimento de tudo pelo caminho mais rápido e mais econômico e, no mesmo instante e com a mesma rapidez, tudo se esquece (HEIDEGGER, s.d., p.11).

No entanto, Heidegger vê uma saída para a armadilha e para a "armação" perpetrada pela sociedade tecnocrática em relação ao homem e esta se encontra no contexto da reflexão, à medida que o ser humano pode se tornar consciente dessa determinação e passar a ser sujeito de suas escolhas por intermédio de um pensamento mais libertador que o emancipe da exclusividade do pensar técnico. Aponta aí para a linguagem poética como uma possibilidade de libertação.

A Literatura Brasileira, sobretudo a do final do século XIX, vai se contaminar pelo pensamento técnico, aproximando a linguagem e o cenário literários de determinada perspectiva científica. $\mathrm{O}$ escritor, imbuído de certa crença no paradigma científico, opta por uma linguagem que se pretende imparcial, objetiva, descritiva e fotográfica do real. Utilizam-se narrativas, criando enredos e personagens, para comprovar teses consideradas científicas sobre patologias hereditárias e determinismos raciais e étnicos. Surgem, então, os romances experimentais, em que o autor se utiliza do espaço literário para demonstrar a causalidade e os efeitos de determinados comportamentos, como se o romance fosse um laboratório em que a experiência humana é descrita e revelada em pormenores e em sua totalidade, isenta de mistérios e de dúvidas. O autor, a partir de um narrador pretensamente imparcial e munido de perspectiva científica, paira acima de seu objeto de estudo, o próprio homem, decifrando-o. Alguns escritores, no entanto, são céticos em relação a essa aproximação e passam a questionar os dados científicos, satirizando o cientificismo da época. Este é o caso do escritor Machado de Assis (1839-1908), que se afasta do afã de legitimar o discurso literário a partir do paradigma científico da época. Duvida desse poder de o romancista explicar os móveis da ação humana a partir de uma linguagem que nega a ambiguidade, a problematização, a reflexão e se quer objetiva, clara e definitiva. Machado longe se acha dessa inflexão do literário, pois a sua escrita revela o contrário, ou seja, a descrença nesse paradigma cientificista. Assim, pode-se ler Machado de Assis tendo por base o ideário 
heideggeriano em que se critica essa vontade de controle que se dá a partir, inclusive, de uma linguagem técnica, a qual visa denominar, nomear, classificar, discriminar o mundo, igual a um Adão Mítico, sem o transcendente, a fim de se apossar desse mundo, objetificando-o e apaziguando-o. Este pensamento maquinístico anseia de tudo se apoderar, gerando uma sociedade tecnocrática em que a taxinomia é o caminho para a descrição e para a definição de tudo à imagem do homem. Impera, pois, uma metafísica da representação, em que tudo é dado como imagem controlada e construída a partir do linguajar e da atitude técnicos.

Com base nessa perspectiva crítica sobre o pensar técnico e seu contrário, ou seja, o pensamento reflexivo via linguagem literária, estabelece-se uma leitura do conto como possibilidade de interpretar o pensamento de Machado de Assis enquanto abertura para tal reflexão, uma vez que a narrativa demonstra os descaminhos que a "armação" da linguagem técnica provoca na comunidade dos homens. Nesse passo, acredita-se que, via apreciação da linguagem literária, pode-se chegar à reflexão sobre esse pensar técnico que, segundo o filósofo alemão, tem se tornado forte e avassalador para o homem ocidental. A saída para essa "armação" técnica está na adoção de outra perspectiva, em que a linguagem reflexiva é possível solução para recuperar as verdadeiras raízes do ser humano, ou seja, a sua capacidade de meditar.

\section{Resumo interpretativo do conto e questões de linguagem}

O conto O Alienista narra, resumidamente, a vinda do médico psiquiatra Simão Bacamarte para a cidade de Itaguaí, na época do vice-reinado no Brasil Colônia, a fim de implantar uma casa de tratamento para doentes mentais, chamada Casa de Orates ou Casa Verde. O médico, munido de discurso competente, balizado no estágio das ciências da época, tem apoio das autoridades políticas e da comunidade para iniciar os trabalhos. O discurso técnico passa, então, a denominar, classificar, discriminar as pessoas da comunidade, alienando-as do convívio social à medida que são enquadradas em diferentes categorias de doenças mentais. A narrativa avança e todas as pessoas são internadas, visto padecerem de algum mal diagnosticado por intermédio do discurso técnico de que se investe Simão Bacamarte. Todos recebem um dado diagnóstico e certa denominação que indica uma patologia. São internados e exilados do convívio social por intermédio de um discurso que os objetifica e os domina. No entanto, com o desenrolar da narrativa, o médico vai liberando um a um, pois 
os toma como curados, após longo processo de tratamento. A fábula avança, demonstrando contradições do discurso maquinístico, pois, após a liberação, os equilibrados passam a ser exilados, dados como doentes. Todos padecem de algum mal, quer sejam considerados normais ou não. Ao final da narrativa, em revés satírico e inusitado, o médico, após “desalienar" a todos, resolve se autointernar, visto que percebe a perfeição em si, uma vez que fora o único a não ser exilado. Decorre daí a mudança de sua teoria, ou seja, o desequilíbrio passa a ser normal e o equilíbrio indica a doença.

Essa virada da fábula provoca a quebra de distanciamento entre o sujeito e o objeto do estudo, pois eles se fundem, haja vista o médico e o paciente serem a mesma pessoa. Com o avançar da fábula, a linguagem técnica vai se apossando do sujeito. No início da narrativa, o sujeito (cientista e médico) ainda a domina parcialmente, utilizando-a para analisar e representar o outro e curá-lo. Há certa posse dessa linguagem em que ela se submete aos desígnios do médico. Entretanto, o médico já se revela dominado por essa linguagem técnica à medida que interna a todos, não percebendo o controle da linguagem sobre si. Parece haver anulação do sujeito e quem fala por ele é a linguagem. O discurso contrário da comunidade, que passa a duvidar e a temer esse discurso, não é agregado pela instância discursiva, que permanece fechada ao debate. Não ocorre nenhum embate discursivo dialógico entre o discurso da comunidade, que passa a duvidar de Simão Bacamarte, e o discurso científico que emite. Ao final da narrativa, quando o médico interna a si mesmo, percebe-se que fora tomado totalmente pela linguagem da técnica, que anula o sujeito reflexivo. A linguagem técnica se fortalece no seu objetivo de discriminação e de controle.

Essa autonomia da linguagem técnica também pode ser observada se refletirmos sobre o espaço geográfico de onde ela parte. Note-se que Simão Bacamarte, no início, encontrava-se em dois lugares alternadamente, ou seja, dentro da Casa Verde, definindo o diagnóstico e administrando a cura, e fora dela, na comunidade, observando o cotidiano e dali retirando os doentes. A personagem pode transitar por esses dois espaços livremente porque ainda tem poder sobre o discurso competente que ainda não o aprisiona totalmente. Já a comunidade ou está fora ou dentro da Casa Verde. Quando ali adentra é sinal de que padece de algum mal e desse espaço só sai com autorização médica. O médico, via discurso técnico, é quem dá a liberdade ou a detenção. Ao final da narrativa, no entanto, quando o cientista se interna, neutraliza-se o seu livre trânsito entre a comunidade e a Casa Verde. 
O mínimo de espaço de liberdade de movimentação de que dispunha é anulado. Isso sinaliza para um triunfo da linguagem técnica sobre o sujeito. Simão Bacamarte se encontra, derradeiramente, assujeitado ao discurso. O domínio da linguagem sobre o sujeito se exacerba quando ocorre essa troca de papéis, pois o médico passa a ser o investigado, fundindo-se sujeito e objeto de pesquisa, parecendo ser a linguagem a detentora do controle. $\mathrm{O}$ princípio da discriminação e da separação se avulta sobre qualquer outro. Não importa o quê se estuda e para quê, mas se autonomiza a vontade de separação e de controle. Simão Bacamarte não está doente e deve ser curado. Goza de perfeita saúde mental, denominando-se perfeito, mesmo assim deve ser estudado, agora, em contraposição à imperfeição.

Esse revertério da fábula leva à reflexão sobre a competência, a precisão e a objetividade do saber técnico, que é carnavalizado ${ }^{3}$ ao final, pois encerra na casa de saúde o elemento sadio. O objetivo desse saber não é curar, integrar à comunidade, mas continuar discriminando. Entretanto, essa fábula é narrada pelo discurso literário e este, ao usar de certas estratégias composicionais como a caricatura, a hipérbole, o conflito discursivo, a sátira e a carnavalização, esvazia esse discurso, revelando suas limitações e sua irracionalidade.

O discurso do médico revela-se ambíguo, incerto e capaz de se transformar em armadilha e em "armação" tanto para aquele que o emite quanto para aqueles que são representados por esse discurso. A representação e a objetificação das coisas viventes podem ser ideais e desejos humanos, mas que não se cumprem facilmente. Entre as palavras e as coisas há um conflito muito grande. As coisas ora se deixam representar pela linguagem, ora lhe fogem. A partir da linguagem da reflexão que a literatura pode propiciar, veem-se essas limitações discursivas da linguagem técnica. O leitor tem a

\footnotetext{
${ }^{3}$ O termo se vincula a Bakhtin (1987), para quem o espírito crítico e de contestação da ordem que impera nas festividades carnavalescas na Idade Média e no Renascimento migra para a literatura, denominando-se "carnavalização". Esta é uma das categorias que fundamentam o pensamento ético, político e estético do pensador russo, sendo responsável diretamente por dessacralizar os discursos canônicos e destacar o princípio do contraditório, do ambivalente e da alteridade. Bakhtin usa esse termo descrevendo-o como expediente literário cujo objetivo é o questionamento do discurso único, unívoco e autoritário. Todo discurso fechado ao diálogo e que se pretende verdadeiro e inquestionável é objeto de carnavalização no gênero romanesco. No conto em tela, as limitações do discurso monológico são expostas por meio da carnavalização. Esse expediente consiste em desarticular a ordem estabelecida, sobretudo, pela visualização do absurdo, do hiperbólico, da radicalização das situações e do processo de destronamento do que é considerado normal e equilibrado.
} 
visão exotópica ${ }^{4}$ por intermédio de um narrador que constitui formalmente a fábula, satirizando o discurso maquinístico, percebendo a falácia do discurso. Vê também o poder desse discurso, pois, distante da reflexão, pode se apoderar tanto do sujeito que o emite quanto dos demais sobre os quais age, definindo-os e reificando-os.

\section{Elementos composicionais da fábula e possibilidade de reflexão}

Tendo-se essa leitura inicial, o artigo, doravante, propõe-se a explicitar, a partir de situações discursivas narrativas do conto, esse conflito e essa carnavalização da linguagem técnica, enfocando, sobretudo, a personagem Simão Bacamarte, sua origem, sua prática médica e seu destino no decorrer da narrativa. A narrativa resiste ${ }^{5}$ à linguagem técnica por intermédio de elementos composicionais como a sátira, a carnavalização, a exotopia, a dialogia contextual, a focalização em terceira pessoa, a linguagem de cronista distanciado do narrador e a questão da temporalidade narrativa. Esses elementos formais constituem estrutura arquitetônica ${ }^{6}$ de resistência e de reflexão frente às práticas discursivas monológicas.

A narrativa é dada, sobretudo, pela visão de um narrador em terceira pessoa, cuja linguagem recupera as falas e as crônicas do povo em geral que viveu os acontecimentos. Parcialmente colado a essas falas, vai narrando os fatos a partir do olhar dos outros discursos e, assim, formalizando uma batalha discursiva em que a linguagem técnica de Simão Bacamarte vai sendo neutralizada. O discurso de Simão Bacamarte e as atitudes que daí decorrem, pois o discurso instaura uma dada política pública de internamento dos denominados loucos, não são aceitos sem protesto. Entretanto, esse protesto

\footnotetext{
4 Toma-se o termo de Mikhail Bakhtin (1988), para quem o narrador e o leitor têm um excedente de visão em relação ao fato narrado, pois o narrador é o mediador da fábula, podendo criticar, alterar, enaltecer ou deturpar o fato, dependendo de suas intenções discursivas. No conto, vê-se que essa visão exotópica é construída a partir de expedientes formais cujo propósito é criticar o fato, satirizando-o.

${ }^{5}$ Bosi (2002), no capítulo "Narrativa e resistência", explora as articulações entre literatura e contexto histórico, apontando os vários expedientes formais como a sátira e a ironia, que se tornam elementos internos à narrativa, propiciando uma resistência ao discursivo narrativo frente aos fatos sociais e históricos que expõe. O conto, ao questionar o discurso calculístico, opõe resistência a ele.

${ }^{6}$ Bakhtin (1988) usa o termo no sentido de macrovisão do texto literário, ou seja, do prisma pelo qual o autor e o narrador escolhem para estruturar o fato narrativo, podendo ser trágico, cômico, carnavalizado, dramático, entre outros.
} 
não chega a impedir as atividades do médico, mas as colocam em suspeição. A internação dos loucos é vista de modo duvidoso pela população, pois parecia "demência" colocá-los todos juntos, sem apartá-los entre si. Aqui, o encerramento dos loucos corresponde à mudança de paradigma de que trata Foucault (1988), ${ }^{7}$ para quem, no século XVIII, esse internamento, tanto dos loucos quanto dos delinquentes, corresponde ao tratamento da alma e não mais ao suplício dos corpos. Para esse autor, o tratamento da alma, ou seja, da consciência, faz-se por intermédio de vários expedientes ancorados e legitimados por um discurso considerado científico que deseja domesticar e disciplinar a população. A Colônia brasileira, período histórico da narrativa, não se acha isolada desses novos paradigmas. Um dos fatos que atestam essa importação de ideias e de práticas dos países europeus é a instalação da casa de Itaguaí, trazendo certa modernidade para a sociedade local. A linguagem técnica e a intervenção social que operam a Casa de Orates têm respaldo na comunidade internacional, visto que na Europa também ocorrem grandes encerramentos de loucos em período similar. Além disso, essa linguagem tem genealogia nobre, pois Simão Bacamarte formara-se em Coimbra e em Pádua, sinalizando para a legitimidade de seu saber, uma vez que as primeiras faculdades de Medicina no país são implementadas somente no Primeiro Império.

Entretanto, o saber local resiste ao médico, apontando-lhe as incongruências e enfraquecendo-o. O narrador, ao construir a narrativa sobre os fatos, coleta da comunidade, oralmente, informações sobre o acontecido. O narrador, ao incorporar o discurso de outrem, ou seja, da comunidade, desestabiliza a linguagem técnica de Simão Bacamarte. O leitor vai tendo acesso a essas falas contrárias e "lendo" o discurso e as atitudes de Simão Bacamarte por intermédio da dúvida e da sátira, propiciadas por um outro olhar advindo das várias personagens que povoam a narrativa. Entretanto, o discurso

\footnotetext{
${ }^{7} \mathrm{O}$ autor francês, partindo da mudança de paradigma das prisões, enfatiza que o encerramento dos delinquentes na prisão é dado e legitimado por um novo saber, considerado científico, em que se preconiza o cárcere para alterar o comportamento e devovlver o delinquente já curado à sociedade. Vários saberes são chamados para prescrever o diagnóstico, o tratamento e a possível cura com inserção social do malfeitor. Esse agir na consciência do sujeito é algo novo, pois já não se suplicia o corpo. Essa nova episteme extrapola o cárcere e se estende para outras instituições sociais que visam discriminar e domesticar por intermédio de um eterno "vigiar e punir, vigiar e disciplinar": "Devemos ainda nos admirar que a prisão se pareça com as fábricas, com as escolas, com os quartéis, com os hospitais, e todos se pareçam com as prisões?" ( FOUCAULT, 1988, p. 199).
} 
da personagem principal e sua prática estão internamente fechados ao dialogismo, pois não dialogam com essas vozes, nem mesmo para questioná-las. No entanto, quando elas irrompem na narrativa, demonstram que o discurso autoritário é confrontado diretamente por um contexto dialógico que enfraquece a sua monologia. Nessas vozes, o próprio médico é dado como insano:

A proposta (alojar todos os loucos no mesmo espaço) excitou a curiosidade de toda a vila, e encontrou grande resistência, tão certo é que dificilmente se desarraigaram hábitos absurdos, ou ainda maus. A ideia de meter na mesma casa, vivendo em comum, pareceu em si mesma um sintoma de demência, e não faltou quem o insinuasse à própria mulher do médico (ASSIS, 2008, p. 160).

Em outra fala, a voz da personagem Padre Lopes surge confrontando o médico. Note-se que a fala ministerial tem aí certo poder desestabilizador, haja vista que, no Brasil oitocentista, a Igreja Católica exercia ainda um poder político e heurístico bastante acentuado. Há certo embate de posições, pois é uma autoridade, a eclesiástica, tentando enfraquecer outra, a científica. Entretanto, embora haja esse questionamento por parte da instância religiosa, o discurso e as práticas de Simão Bacamarte seguem legitimando os enclausuramentos. O padre questiona, sobretudo, o isolamento do médico em relação à vida social. $O$ discurso científico é dado como fora da realidade e, na lógica da personagem padre, isso o torna menos crível. O discurso rompe os laços com a realidade, transformando-se em um construto ausente de referência material. Nesse passo, outras vozes enredam esse discurso e o relativizam em parte: "Olhe, D. Evarista, disse-lhe o Padre Lopes, vigário do lugar, veja se seu marido dá um passeio ao Rio de Janeiro. Isso de estudar sempre, sempre, não é bom, vira o juízo" (ASSIS, 2008, p. 16).

O discurso técnico e a sua utopia, neste caso a da cura dos considerados "doentes", tomam conta da vida de Simão Bacamarte. O trabalho intelectual o aliena de toda sorte de convívio social que não seja para corroborar a sua tese sobre a loucura e sobre sua cura. O trabalho imaterial o subjuga, pois ele já não se alimenta, não se diverte, e tem tempo muito reduzido para a família e para os amigos. Restringe-se a estudar, a receitar e a empregar tratamentos para os alienados. O alienista vai, aos poucos, transformando-se em alienado, preso pela linguagem técnica que lhe impele ao isolamento dos demais e ao trabalho estafante. Essa atitude hiperbólica de isolamento e de "ideia fixa" de Simão Bacamarte, afeiçoado 
demais à atividade laboral, também coloca sob suspeição as atitudes do cientista, apartado do real e enclausurado no saber técnico. Rompem-se os laços entre vida e trabalho e este assujeita aquela. $\mathrm{O}$ trabalho imaterial do cientista passa a dominar a sua vida, reduzindo-a:

Ora, todo esse trabalho levava-lhe o melhor e o mais do tempo. Mal dormia e mal comia; e, ainda comendo, era como se trabalhasse, porque ora interrogava um texto antigo, ora ruminava uma questão, e ia muitas vezes de um cabo a outro do jantar sem dizer uma só palavra a D. Evarista (ASSIS, 2008, p. 23).

O narrador se utiliza, em várias passagens, dessa inflação que acomete as atitudes da personagem médico, desestabilizando-a. Caricaturiza-o em várias situações, destacando a unidimensionalidade de suas atitudes, ou seja, dominadas pela vontade de controle sobre as pessoas. Em certa ocasião, enfatiza o comportamento policialesco de Simão Bacamarte quando este sai às ruas para observar a comunidade com o intuito de descobrir unicamente o desvio e internar as pessoas acometidas pelas patologias com que as classifica. A associação do trabalho médico ao trabalho policial não deixa dúvidas sobre os propósitos do narrador, ou seja, aproximar de modo satírico e crítico duas realidades bastante contrárias, visto que o aparato policial associa-se mais aos desvios, crimes e desordens sociais e a prática médica aproxima-se mais da saúde física e mental. Entretanto, nessa aproximação, os universos se tornam bastante homogêneos, sinalizando o desequilíbrio da prática médica.

Somando-se a isso, a cada passo, o narrador escolhe determinadas falas da própria personagem para apresentá-la de maneira a enfraquecê-la. $\mathrm{Na}$ fala que segue, Simão Bacamarte utiliza-se de metáforas que criam a imagem do exagero e do descomunal para descrever seu objeto de pesquisa. A linguagem hiperbólica, pouco objetiva e carente de dados estatísticos, mais adequados à linguagem técnica, causa estranhamento, desestabilizando a fala do cientista, como se atesta na seguinte passagem: "A loucura, objeto dos meus estudos, era até agora uma ilha perdida no oceano da razão; começo a suspeitar que é um continente" (ASSIS, 2008, p. 29). A ordem do discurso esperada é rompida, pois a fala é construída por intermédio de uma linguagem inadequada que tende para o vago e para a imprecisão e não para a cientificidade. Em vez de dados mais precisos, tem-se uma linguagem impressionista e metafórica. 
O expediente da carnavalização das situações é a espinha dorsal do pensamento reflexivo que o conto propõe, pois, a partir desse expediente composicional, o discurso técnico se neutraliza à medida que a atitude e o saber de Simão Bacamarte sofrem um destronamento radical, portanto, a tese inicial se transforma em sua antítese ao final, visto que a "perfeição" passa a ser o desvio e não o contrário, como advogava no início. Entretanto, diferentemente da verdadeira carnavalização de que trata o referido filósofo russo, a personagem não se liberta, mas se aprisiona ainda mais, vindo inclusive a falecer. Segundo Bakhtin, a carnavalização é um processo ininterrupto de desentronização e de entronização em que essa dinâmica assegura a revitalização das coisas, dos fatos e do homem. Tudo morre e renasce. A personagem, no entanto, falece, vítima de seu próprio saber. Assim, no espaço restrito da personagem, a carnavalização não ocorre, mas ocorre em âmbito do discurso literário maior, que enquadra o discurso da personagem principal, uma vez que desmonta a tese e revela a antítese também como inapropriada, superando ambas em um processo em que só o pensamento reflexivo é capaz de elaborar. $\mathrm{O}$ narrador e o leitor, mediante a exotopia, têm acesso ao pensamento reflexivo sobre a insanidade de Simão Bacamarte. No excerto a seguir, tem-se a fala da personagem no início de sua trajetória intelectual, destacando a positividade da razão de forma conclusiva e sem dúvidas, ou seja, a razão é a tese e a insânia é a antítese.

- Supondo o espírito humano uma vasta concha, Sr. Soares, o meu fim é ver se posso extrair a pérola, que é a razão; por outros termos, demarquemos definitivamente os limites da razão e da loucura. A razão é o perfeito equilíbrio de todas as faculdades; fora daí insânia, insânia, e só insânia (ASSIS, 2008, p. 31).

Essa tese inicial, ao fim, é então constatada falsa, transformando-se em antítese. A derradeira tese a que Simão Bacamarte se aferra é a de que o equilíbrio é a loucura e não o contrário. A carnavalização atinge seu ápice como elemento formal que leva o leitor à reflexão. A tese morre, vem no lugar o seu contrário e o dinamismo dessa gangorra discursiva revela as incongruências da linguagem técnica:

Simão Bacamarte achou em si os característicos do perfeito equilíbrio mental e moral; pareceu-lhe que possuía a sagacidade, a paciência, a perseverança, a to- 
lerância, a veracidade, o vigor moral, a lealdade, todas as qualidades enfim que podem formar um acabado mentecapto (ASSIS, 2008, p. 86).

Não se vê aí uma síntese final que apazigue as diferenças e os embates dos contrários. Há, sim, uma eterna agonística em que nada tem estabilidade e essa fluidez contamina o discurso técnico que perde seus referenciais lógicos.

Várias descrições da personagem se dão a partir de uma linguagem em que a escolha dos vocábulos aproxima-se de um campo semântico vinculado a realidades distantes da imagem da ciência e do cientista em que se preconizam a objetividade, o equilíbrio e o bom senso. Nos excertos que seguem, o narrador carrega nos vocábulos que descrevem Simão Bacamarte como desequilibrado, desestabilizando sua postura imparcial. Os vocábulos e as construções linguísticas revelam uma faceta nada pacífica do cientista: "Bacamarte espetara na pobre senhora um par de olhos agudos como punhal" (ASSIS, 2008, p. 35). Ainda: "Uma volúpia científica alumiou os olhos de Simão Bacamarte" (ASSIS, 2008, p. 38). E, na fala que segue, o terror que assola a comunidade, tendo em vista a possibilidade da internação quando se é interpelado pelo médico: "Todo o tempo que lhe sobrava dos cuidados da Casa Verde era pouco para andar na rua, ou de casa em casa, conversando as gentes, sobre trinta mil assuntos, e virgulando as falas de um olhar que metia medo aos mais heróicos" (ASSIS, 2008, p. 27).

Parte da população, desolada com os desmandos da ciência, passa a hostilizar o alienista, solicitando a interdição do cientista, descrevendo-o como "déspota", "violento", "Golias" e vendo a Casa de Orates como a Bastilha da Razão e o alienista como o alienado. Essa inversão da ordem, no entanto, não culmina com sua interdição, pois não é constante. A comunidade ora o critica, ora o enaltece, demonstrando-se também incoerente. Ao final da narrativa, apesar dos protestos contra o cientista, este, após falecer na Casa de Orates, é sepultado com honrarias e condecorações. Na fala do narrador tem-se: "Seja como for, efetuou-se o enterro com muita pompa e rara solenidade" (ASSIS, 2008, p. 88).

$\mathrm{O}$ autor, em mais um revés da narrativa, revela a inconstância tanto do alienista quanto da comunidade. Localiza a desmedida e a incoerência em todos. A comunidade e o cientista, enfim, estão irmanados, sendo igualmente desprovidos de racionalidade que lhes possibilite uma tomada de ação coerente e constante. Antes, desnuda-se a ausência de pontos fixos, de 
valores perenes, de resultados definidos e a eterna oscilação entre a ordem e a desordem, a tese e a antítese, em uma agonística em devenir. A linguagem calculística de que trata o filósofo alemão é uma quimera, pois na prática daquela comunidade o que prevalece é a constância de um movimento de entronização e de desentronização da razão e da insanidade. O discurso literário representa essa dinâmica em que o discurso monológico tem dificuldades de ser hegemônico. A representatividade dessas vozes e atitudes em conflito é uma forma de resistência do discurso literário frente à linguagem e ao pensar técnicos.

Outro expediente narrativo usado para desequilibrar o discurso e as atitudes de Simão Bacamarte refere-se à relação entre tempo da escritura e tempo da fábula. $\mathrm{O}$ narrador se acha afastado em décadas do fato ocorrido e dele toma ciência pelas falas da comunidade que se preservaram durante muitos anos. O feito foi marcante para a comunidade e isso se comprova pela sua manutenção na memória discursiva popular. $\mathrm{O}$ escritor, como se viu já neste artigo, viveu em um tempo em que o paradigma cientificista se tornava bastante forte, tanto nos países centrais europeus quanto nos periféricos, que importavam o conjunto de ideias e de práticas centrais a fim de se modernizarem. A opção machadiana por localizar a fábula em período bem anterior à escritura da obra propicia uma crítica ao presente do escritor e ao cientificismo que adentrava inclusive muitos romances de seus colegas contemporâneos. O escritor, assim fazendo, demonstra que o cientificismo dominante na época já tinha gerado malefícios muito anteriormente. Havia memória local, resgatada pela literatura, que atestava tais limitações. Esse resgate temporal leva a refletir sobre o novo e sobre o presente, percebidos como velhos. O diálogo temporal desacredita o discurso científico ao demonstrar que este não se encontra no topo do saber, sendo última novidade e conquista temporal. Rompe-se a ideia de linearidade progressiva do saber, ao revelar o embuste do saber técnico por intermédio de sua localização no passado em que gerou mais malefícios que benefícios.

\section{Considerações finais}

Simão Bacamarte, em vez de se aproximar dos homens e deixá-los se "apresentar", representa-os, aprisionando-os e reduzindo-os a certas definições e patologias. O discurso técnico se apodera de seu agir, impedindo-o de interagir com o outro. $\mathrm{O}$ discurso do outro não entra em processo dialógico com Simão Bacamarte. Desconhece a interação, pairando 
dominador e avassalador sobre os demais. Não demonstra nem cautela, nem "serenidade" para com o outro. Pretende dominá-lo, impingindo-lhe nomeações, tratamentos e curas. Quando se aproxima do outro, neutraliza o seu pensar, a sua linguagem e o seu agir. A prepotência do saber técnico desconhece as outras formas de pensar e de agir. Quando se aproxima de si mesmo, internando-se para estudar a si mesmo, neutraliza-se, pois em si já não habita o pensamento reflexivo, que fora tomado pelo pensar calculístico. Essa dominância, leva-o à morte, porque impera a linguagem técnica sobre o ser, enfraquecido e combalido pela ausência de reflexão. A razão, tão cara ao médico, é uma irracionalidade, pois o afasta de seus semelhantes e o leva à morte. O trabalho científico é árduo, escravizante e alienante. Simão Bacamarte representa o homem enredado pela "armação" do discurso técnico que destrói a verdadeira essência do homem, segundo Heidegger, ou seja, a sua capacidade de pensar, meditar, refletir e agir sem a vontade de tudo dominar.

No entanto, o discurso literário, sobretudo a partir de certos expedientes composicionais como a sátira, a carnavalização, a hipérbole, a linguagem inflacionada, a dialogia, a pluralidade de vozes, revela as limitações do discurso técnico, demonstrando-se reflexivo, visto que problematiza a monologia desse discurso, ausente de interação e de embate público. A literatura é fundamentalmente a representação dos discursos sociais e de sua problematização. Aí, certamente, reside sua capacidade de resistência aos discursos fechados, monológicos e autoritários, apontando para a grande utopia de que trata Heidegger, ou seja, a capacidade de refletir sobre como pensamos e falamos e sobre como podemos estar sobredeterminados por um pensar maquinístico que tudo tenta dominar, exaurir e representar, evitando o "aproximar-se" com cautela e serenidade das coisas e das pessoas em um novo olhar ético e estético capaz de desvencilhar-se da vontade e do poder sobre "o todo do mundo".

\section{Referências Bibliográficas}

BAKHTIN, Mikhail. Cultura popular na Idade Média e no Renascimento: o contexto de François Rabelais. Trad. Yara Frateschi Vieira. São Paulo: Hucitec/Editora Universidade de Brasília, 1987.

BAKHTIN, Mikhail. Questões de literatura e estética: a teoria do romance. Trad. Aurora Fornoni Bernardini et al. São Paulo: Editora Hucitec, 1988. 
BOSI, Alfredo. Literatura e resistência. São Paulo: Companhia das Letras, 2002.

HEIDEGGER, Martin. Serenidade. Trad. Maria Madalena Andrade; Olga Santos. Lisboa: Instituto Piaget, s.d.

HEIDEGGER, Martin. A questão da técnica. In: HEIDEGGER, Martin. Ensaios e conferências. Petrópolis: Vozes, 1992.

FOUCAULT, Michel. Vigiar e punir: História da violência nas prisões. Trad. Ligia M. Ponde Vassalo. 6 ed. Petrópolis: Vozes, 1988.

MARCUSE, Herbert. Ideologia da sociedade industrial. 5 ed. Rio de Janeiro: Zahar, 1979.

MACLUHAN, Marshal. Os meios de comunicação como extensões do homem. Trad. Décio Pignatari. São Paulo: Editora Cultrix, 1969.

RÜDIGER, Francisco. Martin Heidegger e a questão da técnica: prospectos acerca do futuro do homem. Porto Alegre: Sulina, 2006. 